\title{
The Effectiveness Gender Role Analysis Technique to Increase Self Esteem of Bullying Victims in Adolescent
}

\author{
Nur Sholehah Dian Saputri* \\ Postgraduate of Guidance and counseling \\ Universitas Negeri Yogyakarta \\ Yogyakarta, Indonesia \\ nursholehah.2018@student.uny.ac.id*
}

\author{
Sigit Sanyata \\ Guidance and Counseling Department \\ Universitas Negeri Yogyakarta \\ Yogyakarta, Indonesia \\ sanyatasigit@uny.ac.id
}

\begin{abstract}
Adolescent association in the new social environment makes teens interact more with the surrounding environment and their peers. In adolescent friendship relationships, bullying becomes a frequent issue. The problem of bullying in Indonesia is still relatively high. Various kinds of bullying are experienced by students at all levels such as being intimidated, ostracized, insulted, threatened, pushed by their friends and gossiped by their friends. Bullying is felt more by women than men. A special action is needed so that a woman feels more empowered. Gender analysis in feminist counseling is considered to be able to increase self-esteem This research concluded that there is an influence of the use of gender role analysis techniques on increasing self-esteem of victims of bullying.
\end{abstract}

Keywords- feminist counseling, gender role analysis, selfesteem, action research, bullying victim

\section{INTRODUCTION}

Bullying cases occur a lot in Indonesia, which involves school students [1]. About $41 \%$ of students in Indonesia reported being bullied at least a few time a month. By age, middle school students are adolescence [2]. Adolescence is characterized by social and cognitive changes very rapidly. Adolescents are vulnerable to depression, anxiety and low self-esteem. Biological, psychological and social systems undergo marked developmental changes during adolescence [3]. Family support for adolescence has directed and indirected associations with depression, anxiety, stress and well-being through self-esteem [4]. And peer support only showed a direct positive association with well-being [5]. Mahaffari study show a positive relation among gender, adolescent and self-esteem [6]. Girls have higher anxiety than boys [7]. Low self-esteem has a correlation with depression. Older adolescents are more likely to have lower self-esteem and greater depressive symptoms. Conversations about appearances are most common in adolescent girls [8]. Various criticisms about the appearance and body of the spotlight in adolescents and make adolescent have lower self esteem. Furthermore, a study of girls aged 11-16-years found experimental exposure to either ultra-thin or average size magazine models lowered body image satisfaction and consequently self-esteem [9]. Younger girls have lower self- esteem than older adolescent. This research is about selfesteem the bullying victim in adolescence [10]. Other research results show that there is a significant relationship between self-esteem and bullying. The relationship is inversely proportional, where if self-esteem is high then bullying is low and if self-esteem is low then bullying is high. Various experiences of women who are not valued as an individual make the bullying victims lack of self-respect. If that happens someone will tend to be inferior, inappropriate, feeling weak, sense of inadequacy, which will cause the individual to experience emptiness, doubt, and despair in facing the demands of his life. Self-esteem to be a reflexive, context-specific process, which is changeable over the life span [11]. People who have high self-assessment and high self-esteem generally accept their own state [12]. Those who value themselves negatively have feelings of low self-esteem, low self-esteem, or low self-acceptance. The awareness of others is a continuing factor of life and has a broad evaluative component [13].

The hypothesis of this research is gender role analysis is effective to improve self-esteem the bullying victims in an adolescent. The perspective and experience of marginalized and traumatized individuals are a feminist therapy privilege. The aim of feminist therapy is to help clients develop feminist consciousness or awareness that their suffering is not because of personal deficits, but she has been systematically excluded and silenced because of membership in a nondominant group in society [14].

Gender roles are the roles that men and women are expected to occupy based on their sex. Gender role analysis explores and assesses the impact of gender role expectations on the psychological well-being of the counselee and uses the results of this analysis to make decisions about gender role behavior in the future [15]. Gender role analysis has a role to support counselee change. There are five elements in gender role analysis, namely norms in gender, social variables, qualitative and quantitative data, weaknesses and strengths of each gender, and differences in scope and method. Norms in the gender is information about women and men, adolescent in terms of work, role and responsibilities, access and power, income, and position in society [16]. Gender analysis - principles and elements deal specifically with the shortcomings of men and women and 
young women and men. Besides that, in terms of the intended strength, it is about the role and influence of a man or woman in his group. Differences in the scope and methods of gender analysis can vary and differ depending on the context being discussed or analyzed. Based on the description, researchers do this research and apply feminist counseling to solve the problem of self-esteem in the bullying victims.

\section{METHODS}

This research is action research. Research is integrated into real education settings so that they can directly influence the development of existing educational practices. The most striking thing in this action research is there is a change in counselee and provides alternative counseling for practitioners or school counselors. The data in this research this research are self-esteem scale, observation and interview. The self-esteem scale in this research is self-esteem scale with 49 questions with Alpha Cronbach reliability test results with 0.866 results made by Saputri [17]. Interviews are conducted after participants are given the form of counseling action. The interview material includes the implementation of actions that have been received, understanding gender before and after counseling, and gender bullying.

Research participants are teenage victims of bullying with gender bullying specifications. Before treatment in the form of counseling was done, researchers previously measured the level of self-esteem of each participant or counselee. The research participants said that all research-related data, including the content of counseling, were kept confidential and the participant's identity was protected as a counselor. The researchers also said that this study did not affect learning outcomes or anything. Quantitative analysis was used to determine the effectiveness of feminist counseling. Gender role analysis techniques to improve adolescent self-esteem. The analysis in this research the Wilcoxon test statistical analysis. The SPSS results were compared with a value of 0.050 , if it was smaller, meaning that this study was accepted. Hypothesis research is "feminist counseling technique gender effective role analysis in increasing self-esteem of victims of bullying"

\section{RESULT AND DISCUSSION}

The study was conducted on eight participants who were all victims of bullying. The study has two cycles and IT preceded by pre-action. Each cycle uses a gender role analysis technique. Before counseling starts, researchers conduct a pre-action stage to prepare what is needed in the process of providing counseling. The stage are:

1. Prepared instruments will be used in areas like selfesteem scale, interview guidelines, and observation guidelines. The self-esteem scale that was used is a scale that has been created by Saputri [17] and this tested for reliability

2. Determination of research subject obtained from teacher recommendations guidance and counseling and observation of previous researchers
3. Prepare a counseling plan

4. Prepare licenses and other supporting facilities and infrastructure for research.

After the pre-action finish, researchers start at the first stage. To start all of these activities, participants are given a pre-test to find out the level of self-esteem before the action taken. At the next stage, researchers involve the participant in specific issues, identifying themes, and identifying things that are contrary to the participant or Councelee's self with gender role analysis. In the second meeting, entering the stage, of gender role analysis which contains gender and gender differences, the roles of men and women, the roles and social status of a person in a family and school settings and gender equality In the process the researcher gives a question to the counselee about the prepared issue. Second, the counselee is asked to disclose matters relating to the issue that has been given. In addition, the researcher asked the counselee to reveal the experience of bullying that is still felt by the impact and invited the counselee to identify the problem that is being experienced and related to the gender issues discussed earlier. After the second cycle is complete, researchers take data post-test 2 which serves to determine the condition of the counselee's self-esteem level (bullying victims) of both cycles. Post-test 2 is considered a research result because the post-test 2 results are the final measurement after all actions takenResults of pre and post-tests $t$ in SPSS. This is the result of the SPSS Program:

Table 1. Test Statistics analyzed by Wilcoxon Signed Ranks test

\begin{tabular}{|c|c|c|c|}
\hline & $\begin{array}{c}\text { Post Test 1 - Pre } \\
\text { Test }\end{array}$ & $\begin{array}{c}\text { Post Test 2 - Post } \\
\text { Test 1 }\end{array}$ & $\begin{array}{c}\text { Post Test 2 - Pre } \\
\text { Test }\end{array}$ \\
\hline $\mathrm{Z}$ & $-2.173^{\mathrm{a}}$ & $-2.524^{\mathrm{a}}$ & $-2.521^{\mathrm{a}}$ \\
$\begin{array}{c}\text { Asymp. Sig. (2- } \\
\text { tailed) }\end{array}$ & .030 & .012 & .012 \\
\hline
\end{tabular}

a. Based on negative ranks.

Based output of statistics test, Asymp.Sig (2-tailed) in pre-test and post-test 1 show point 0.030 . because the value is smaller than 0,050 . It means that in siklus 1 , selfesteem participant has increased. Next, in Asymp Sig (2 taled) post-test 1 and post-test 2 show point 0,012 . It's smaller than 0,050 and mean on siklus 2 self-esteem has increased. The conclusions from the result of statistical calculations on the pre-test, post-test 1 and post-test 2 show an increase in each cycle.

One of the feminist therapeutic frameworks is to understand low self-esteem [18]. The results of the study show that self-esteem can be improved by one of the techniques in feminist therapy namely gender role analysis. Gender analysis that not only recognizes the role of economic empowerment and equitable distribution of resources but recommends including the concept and role of social capital, equality, and carry out the gender in gender analysis based on the perceived principle of equality, placing men and women in complementary roles that can lead on equality. In this research, the researcher applies the gender role analysis in the form of a discussion of the roles of each gender, the rights and obligations of each gender in 
Indonesian culture, the social roles of women and men, and the gap in social status on gender [19]. Feminist therapy is important with significant therapy goals contribution in relation to women's mental health issues, core issue of feminist therapy goals is self-esteem which discusessed and presented through a specific case study illustration [20]. In each cycle, the researcher carry out the entire technique mentioned. in the post-test results, subjects experienced an increase in each cycle. It can be concluded that there is an influence of the use of feminist counseling in gender role analysis techniques on increasing self-esteem of the bullying victims.

\section{CONCLUSION}

Bullying victims in adolescents have low selfesteem. Low self-esteem has a negative impact on students' learning and social development. Self-esteem improvement can be done in various ways. Curative ways that can be done is by counseling. Various counseling has advantages and disadvantages of each. Gender bullying that occurs can be helped by group counseling. The results of the study showed that feminist counseling with gender role analysis techniques were effectively used in increasing self-esteem. This research can provide input to counselors in the schools and community

\section{ACKNOWLEDGMENT}

On this occasion, the researchers would like to thank student's of Senior High Schools in Yogyakarta who were willing to become participants of this study. Thank you to the State University of Yogyakarta for providing the opportunity, facilities, and encouragement for writing this journal article.

\section{REFERENCES}

[1] Kartika, K., Darmayanti, H., \& Kurniawati, F. (2019). Fenomena Bullying di Sekolah: Apa dan Bagaimana? Pedagogia Social, 17(1), 55 66. https://doi.org/10.17509/pdgia.v17i1.13980.

[2] The Programme for International Student Assessment (PISA). (2018) Programme for International Student Assessment Result from PISA 2018. Retrieved from https://www.oecd.org/pisa/publications/PISA2018_CN_IDN.pdf.

[3] McLaughlin, K.A., King, K. (2015) Developmental Trajectories of Anxiety and Depression in Early Adolescence. J Abnorm Child Psychol 43, 311-323 doi:10.1007/s10802-014-9898-1.
[4] Dante Cicchetti \& Fred Rogosch (2002) A developmental psychology perspective on adolescence. Journal of Consulting and Clinical Psychology. DOI: 10.1037/0022-006X.70.1.6.

[5] Gardner, A. A., \& Lambert, C. A. (2019). Examining the interplay of self-esteem, trait-emotional intelligence, and age with depression across adolescence. Journal of Adolescence, 71, 162-166. doi:10.1016/j.adolescence.2019.01.008

[6] Mahaffy, K. A. (2004). Girls' Low Self-Esteem. Gender \& Society, 18(3), 309-327. doi:10.1177/0891243204263988.

[7] Child Mind Institutr (2017) Anxiety and Depression in Adolescence. Retrieved from: https://childmind.org/report/2017-childrens-mentalhealth-report/anxiety-depression-adolescence/.

[8] Gardner, A. A., \& Webb, H. J. (2017). A Contextual Examination of the Associations Between Social Support, Self-Esteem, and Psychological Well-Being among Jamaican Adolescents. Youth \& Society. doi:10.1177/0044118x17707450.

[9] Cribb, V. L., \& Haase, A. M. (2016). Girls feeling good at school: School gender environment, internalization and awareness of sociocultural attitudes associations with self-esteem in adolescent girls. Journal of Adolescence, 46, 107-114. doi:10.1016/j.adolescence.2015.10.019.

[10]Clay, D., Vignoles, V. L., \& Dittmar, H. (2005). Body Image and SelfEsteem Among Adolescent Girls: Testing the Influence of Sociocultural Factors. Journal of Research on Adolescence, 15(4), 451-477. doi:10.1111/j.1532-7795.2005.00107.x.

[11]Septrina, M.A. (2009). Hubungan Tindakan Bullying Di Sekolah Dengan Self Esteem Siswa. Proceeding PESAT (Psikologi, ekonomi, Sastra, Arsitektur, \&Sipil) Vol 3 Oktober 2009. Universitas Gunadarma retrieved from http://repository.gunadarma.ac.id/749/1/HUBUNGAN\%20TINDAKA N\%20BULLYING_UG.pdf.

[12]Chatham-Carpenter, A., \& DeFrancisco, V. (1998). Women Construct Self-Esteem in their Own Terms: A Feminist Qualitative Study. Jurnal Feminism \& Psychology, 8(4), 467-489. doi:10.1177/0959353598084005.

[13]Burns RB.(1993). Konsep Diri; Teori Pengukuran Perkembangan Dan Perilaku Alih Bahasa: Surya Satyanegara. Jakarta: Arcan.

[14]Crowder, R. (2016). Mindfulness based feminist therapy: The intermingling edges of self-compassion and social justice. Journal of Religion \& Spirituality in Social Work: Social Thought, 35(1-2), 24 40. doi:10.1080/15426432.2015.1080605

[15]Blackstone, Amy. 2003. "Gender Roles and Society." Pp 335-338 in Human Ecology: An Encyclopedia of Children, Families,Communities, and Environments, edited by Julia R. Miller, Richard M. Lerner, and Lawrence B. Schiamberg. Santa Barbara, CA: ABC-CLIO. ISBN I57607-852-3.

[16]Corey, G. (2013). Theory and practice of counseling and psychotherapy (9th ed), Belmont: CA Brooks/Cole.

[17]Saputri, N.S.D. (2017) Peningkatan Self Esteem Korban Bullying Dengan Konseling Feminis. Skripsi. Yogyakarta: UNY.

[18]Greenspan, M. (2017). Feminism, Therapy, and Changing the World. Women \& Therapy, 40(3-4), 334-345. doi:10.1080/02703149.2017.1241573.

[19]Anant Kumar (2016) Complementing Gender Analysis Methods, Journal of Evidence-Informed Social Work, 13:1, 99-110, DOI: 10.1080/15433714.2014.997097.

[20]Draganovic, Selvira. (2012). Approaches to Feminist Therapy: A Case Study Illustration. Epiphany. 4. 10.21533/epiphany.v4i1.34. 